\title{
Implementation of Electronic Budgeting in the Provincial Government of the Special Capital Region of Jakarta
}

\author{
Indrawan Jaya Purnama \& Vishnu Juwono \\ Public Administration Study Program, Faculty of Administrative Sciences, \\ Universitas Indonesia, Indonesia \\ Received: 30 October 2020; Reviewed: 29 November 2020; Accepted: 04 March 2021 \\ * Email Coresponding: indrawanjayapurnama@gmail.com
}

\begin{abstract}
This research is a case study which aims to determine the data input process along with problems in the implementation of e-budgeting in the DKI Jakarta Government and how the suitability of these processes and flows was seen from the Brinkerhoff and Crosby Policy Implementation Theory. Data collection was carried out through field observations, interviewing informants, and documentation. The collected data was then presented and analyzed qualitatively with an interactive analysis model. From the results of data analysis, it was found that the flow of budget input through the e-budgeting application system includes several stages involving government from the lowest level RT / RW to the regent / mayor, provincial DPRD, and the Ministry of Home Affairs starting from the aspiration collection stage, discussion, evaluation, and arrived at the stipulation. Problems faced in the implementation of ebudgeting include errors during budget planning and planning for regional property needs, short data input times, prices and components of goods in the e-budgeting system were not up to date, there was no component or other item that were not suitable with SKPD planning, and the existence of political intervention to support certain political activities. When viewed from Brinkerhoff and Crosby's theory of policy implementation, it was found that the e-budgeting implementation carried out in DKI Jakarta still did not fully fulfill the criteria of the policy theory. It can be seen from the various problems that occurred in the implementation of e-budgeting which contradicts this theory.
\end{abstract}

Keywords: Electronic Budgeting; Budget; Province of the Special Capital Region of Jakarta.

How to cite: Purnama, I.J., \& Juwono, V., (2021), Implementation of Electronic Budgeting in the Provincial Government of the Special Capital Region of Jakarta. Jurnal Administrasi Publik (Public Administration Journal). 11 (1): 42-53. 


\section{INTRODUCTION}

Bureaucratic reform in Indonesia is manifested in the presence of openness and freedom to have access to information. It is one manifestation of the characteristics of e-governance (Naihasy, 2006). Freedom of information, which is known by the openness of information and communication for the public in this era and in the modern era at this time, is an important role for every individual. With the enactment of Law Number 14 of 2008 concerning Public Information Openness, this law has become a moment for the disclosure of information and public services in Indonesia. The enactment of these regulations forms a basis for legal regulations that are used for the right of the public to use public information. Local Governments and other government administrators have the obligation to be able to facilitate and provide services for public information and communication needs in a transparent and fast manner. The availability of information needs in each Regional Government and public agency encourages the realization of good governance (good governance) which includes transparency, effectiveness, efficiency and accountability. When viewed from several aspects that are considered important, good governance includes transparency and openness during the budgeting process.

The budget process aims to establish a Regional Revenue and Expenditure Budget (APBD) for a period of 1 (one) fiscal year. APBD as the basis for local government to manage regional finances in one budget period. Before being ratified and implemented, budget activities must obtain approval through the DPRD, so it is what makes the budget characteristic of supervision and accountability to the public. By reviewing the function of the budget, the budget should be a power relation between the executive, legislature and the people themselves. The DKI Jakarta
Provincial Government by law in particular has Provincial autonomy which means that all policy processes are at the Provincial level including the budget management process. The management of the DKI Jakarta Provincial Government's budget used an e-budgeting application. Ebudgeting was an application or system in its operation using the web (network system) and online, used for budgeting from planning to budget input. This ebudgeting system was integrated with the DPRD and the Regional Development Planning Agency (Bappeda), so that transparently all data can be monitored by the DPRD and Bappeda, so if there are irregularities in the input it will be immediately monitored and must be corrected immediately.

At the end of 2019, politicians and members of the DKI Jakarta Provincial DPRD elected from the Indonesian Solidarity Party (PSI) criticized the fantastic amount of budget that was input through the e-budgeting system/application. The budget is the procurement of aibon glue at the Regional Education Office of West Jakarta Administration City of 82.8 billion, the procurement of ballpoints at the Regional Education Office of East Jakarta Administrative City of 124 billion, the procurement of computers totaling 7,313 computers at the Education Office worth 121 billion and procurement of servers and storage at the Office of Communication, Informatics and Statistics amounting to 66 billion. This irregularity was also confirmed by the Governor-elect of DKI Jakarta Province (2017-2022) Anies Baswedan also confirmed it. The Governor of DKI Jakarta Province found several irregularities in the budgeting for Fiscal Year 2020, including the construction of a bicycle lane of $\mathrm{Rp} 73.7$ billion, Rp. 124 billion ballpoint pens, Rp 121 billion in computer purchases, 407.1 billion printer ink, and 213.3 billion paper purchases. (Kompas, 2019). 
Table 1. Fantastic Budget Findings in the 2020 Budget Planning

\begin{tabular}{|c|c|c|c|}
\hline No. & Regional Work Units & $\begin{array}{l}\text { Total Direct } \\
\text { Expenditure Budget }\end{array}$ & Findings \\
\hline 1. & $\begin{array}{l}\text { West Jakarta Region } 1 \text { Education Sub- } \\
\text { Department }\end{array}$ & $269,336,912,809$ & $\begin{array}{l}\text { Procurement of aibon } \\
\text { glue } 82.8 \text { billion }\end{array}$ \\
\hline 2. & $\begin{array}{l}\text { East Jakarta Region 1 Education Sub- } \\
\text { Department }\end{array}$ & $414,126,996,718$ & $\begin{array}{l}\text { Procurement of } 124 \text { billion } \\
\text { ballpoint pens }\end{array}$ \\
\hline 3. & DKI Jakarta Provincial Education Office & $4,625,272,149,718$ & $\begin{array}{l}\text { Procurement of } 7,313 \\
\text { computers } 121 \text { billion }\end{array}$ \\
\hline 4. & $\begin{array}{l}\text { Department of Communication, } \\
\text { Informatics and Statistics }\end{array}$ & $247,211,930,022$ & $\begin{array}{l}\text { Procurement of servers } \\
\text { and storage, } 66 \text { billion }\end{array}$ \\
\hline
\end{tabular}

Source: Bappeda DKI Jakarta Province

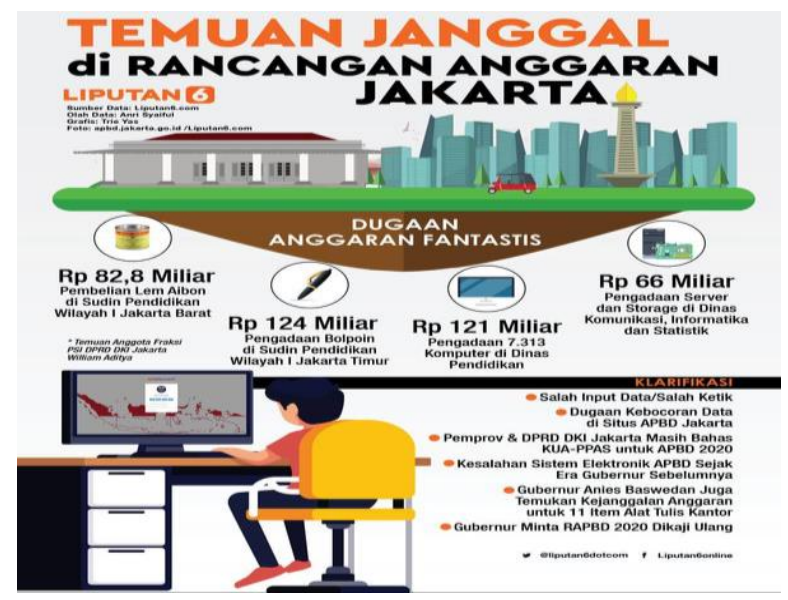

Figure 1: Fantastic budget findings in SKPD / UKPD budget planning

Image Source (liputan 6.com)

Apart from these problems, it turned out that the e-budgeting implemented by the DKI Jakarta Provincial Government also had technical obstacles, including several problems that often arise during budget planning in the e-budgeting system. First, there were components that were not in accordance with the needs, so that the SKPD / UKPD organization must transfer them to other components and had an impact on certain components whose numbers are too large. Second, the submission of the process of changing or adding components takes a long time so that it had the effect of reducing the running time of the budget. Third, differences in system prices and market prices made it difficult for budget planners to input into the e-budgeting system.

Based on the data above, the researcher wants to observe how the budgeting process for the implementation of e-budgeting policies in the DKI Jakarta Provincial Government. The purpose of taking the theme of this manuscript is to observe how the e-budgeting implementation process was in the DKI Jakarta Provincial Government so that at the end of 2019 there was a very significant budget for several SKPD / UKPD that needed to be reviewed.

Previously, several researchers have conducted studies on the use of ebudgeting. Nasution \& Atika(2019) conducted research on the implementation of E-Budgeting as an Effort to Increase Transparency and Accountability of the Local Government of Binjai City. Using performance-based budgeting theory to analyze the role of ebudgeting in increasing the accountability and transparency of the Government, especially the Surabaya city government. His contribution to further research was implementing the e-budgeting application for government SKPD / UKPD and analyzing whether this e-budgeting can create organizational accountability and transparency.

Andriyanto et al. (2019) conducted study on "Antecedents of E-budgeting Use Behavior: The Case of Village Financial Information Systems in Banyuwangi, Indonesia". Using the UTAUT model theory which consists of several variables, namely performance expectations, business expectations, social influence, facilitating conditions, behavioral interests, user behavior, gender, age, experience, and user volunteerism. The research 
contribution was used to examine the person / person inputting e-budgeting.

Khoirunnisak et al. (2017) conducted study on E-budgeting budgeting policies with the spirit to combat various forms of fraud in local government. Case Study of the City Government of Surabaya. But the journey was not easy to carry out due to several factors that hinder the implementation of e-procurement. The study conducted has the aim of explaining the implementation of e-budgeting in Surabaya City, East Java Province, and looking at several factors that become obstacles in the implementation of ebudgeting. On the other hand, the success of several indicators of e-budgeting implementation had become a benchmark for the creation of good governance in the Surabaya City Government.

Zarnelly (2017) conducted research on E-budgeting Information Systems Using an Object-Oriented Approach (Case Study: Uin Suska Riau). Every period, all faculties and units in the State Islamic University of SUSKA RIAU proposed a budget activity program aimed at the Planning Department. After that the planning section discusses it with the leaders. Problems that often arise were budget activities that did not appear, without the knowledge of study programs and faculties, low budget realization and financial reports that have not been achieved optimally. All proposals proposed by the unit and faculty will be discussed by the Planning Department, misunderstandings occurred several times, the Planning Department was often found eliminating activity budgets without prior confirmation, so that the impact was that the faculty and units were forced to carry out these activities. In addition, oversight of budget implementation has not been carried out optimally, so that the treasurer or the Finance Department has difficulty accumulating the budget that has been absorbed or not. The difficulty in reporting also encountered problems, because the reports were done manually. Anticipating the problems above, an application or system was needed to assist the planning. The Planning Section and the Finance Section must be mutually sustainable and coordinate well in planning budget activities, so that activity proposals were achieved that were in accordance with the proposals and can be realized in real terms, then the application or system to be built was e-budgeting, an object-oriented method, which was used were UML diagrams to visualize business processes, such as Use Case Diagrams, Class Diagrams, Sequence Diagrams and Activity Diagrams. This system has the hope of being able to solve all financial problems at the State Islamic University of SUSKA RIAU.

Sakapurnama and Safitri (2012)studied on "Good Governance Aspects in the Implementation of the Transparency of Public Information Law (Good Governance Aspects in the Implementation of the Transparency of Public Information Law) case studies of the City of Surakarta and West Lombok". Using Elson's (2006) policy implementation theory which includes Policy output from implementators, how to target group obeyed the policy output, real life impact of policy output, perception impact of policy output, basic improvements in the law. The theory used by Elson (2006) did not discuss the impact of implementation, so it wasless relevant. For this reason, policy implementation required an analysis of the impact of the policy.

Based on previous research as mentioned above, it can be concluded that e-budgeting was only used as a tool to facilitate a job within an organization, but it was not seen from the policy side of an organization. Novelty. The study to be carried out is that the study will discuss the implementation of e-budgeting in the Provincial Government of DKI Jakarta using the theory of implementation of 
Brinkerhoff and Crosby policies.(Eduardo Araral, Scott Fritzen, Michael Howlett, M. Ramesh, 2012).

\section{RESEARCH METHOD}

This research paradigm used the post positivism paradigm. Post positivism demands clear, accountable data that was in accordance with the facts in the field. The research method that will be used is qualitative research methods. Please(2013) explained that qualitative research methodology was a research procedure that produced descriptive data in the form of written or spoken words from people and observed behavior. Qualitative research methods used human instruments with inductive data analysis based on facts, then constructed a hypothesis or theory. The objective of this study was to understand the implementation of e-budgeting in the Provincial Government of DKI Jakarta, as well identify the problems that occurred in the implementation of budget input in the e-budgeting system so that a solution can be drawn to these problems.

The data used in this study consisted of primary data and secondary data. Data collection was carried out through interviews, documentation and observation. Structured interviews were conducted to obtain the primary data needed in this study. To obtain the required data, researchers interviewed the Head of the Regional Development Planning Agency (Bappeda) of DKI Jakarta Province, Head of the Regional Financial Management Agency (BPKD) of DKI Jakarta Province, Community. Documentation was carried out through collecting and observing Budget Implementation Documents (DPA) for the 2018-2020 Fiscal Year, SKPD / UKPD Work Plans for Fiscal Year 20182020, Government Agency Performance Accountability Reports (LAKIP). While observations were made by observing the Regional Development Planning Agency (Bappeda) of DKI Jakarta Province.
The data collected was analyzed qualitatively, namely the analysis was carried out by working with the data, sorting it into manageable units, synthesizing, looking for and finding patterns, finding what was important and what must be studied to decide what to conclude in Moleong's research (2010). Data were analyzed using and interactive model consisting of three stages, namely data reduction, data display, conclusion / verification (Miles \& Huberman, 1994).

\section{RESULTS AND DISCUSSION \\ Data Input Flow and Problems in Implementing Electronic Budgeting}

The DKI Jakarta Provincial Government was a special area that was regulated through Law Number 29 of 2007 concerning the Provincial Government of DKI Jakarta. The specificity of this law made the Provincial Government of DKI Jakarta as an autonomous region to have discretion, one of them is budget management. Management in the budget sector in particular by the DKI Jakarta Provincial Government started from the lowest level of government, namely Neighborhood Association (RT / RW). The Neighborhood Association (RT / RW) acts as a collector of the aspirations of the citizens / community to find out what needs were needed. In the data collection stage at the RT / RW level, the heads of RT/ RW and residents must play an active role in channeling their aspirations and then input the budget through the Village / Districts apparatus submitted by each RT / RW.

The next stage was the stage of development planning deliberation (musrenbang) starting from the lowest level of government, namely Village / Districts, Mayor / Regent of Administration, Province. In this session or this stage, budget input activities were carried out through the e-budgeting system. After the musrenbang stage was completed, the stakeholders were called upon to provide 
information regarding the proposed needs. The needs of each proposed regional unit / apparatus from the RT / RW had differences from each proposal, which then must be accounted for through the sharpening forum, this sharpening forum was discussed with the Governor and DPRD with the aim of knowing the truth and importance of the proposal to be included in the activity. priority.

Priority activities were determined through the Governor's Regulation on the Regional Development Work Plan (Pergub RKPD) which then became the basis for the preparation of the Temporary Budget Ceiling Priority General Policy (KUA-PPAS). In the KUA-PPAS phase, the submission of activity needs was conveyed to the Governor and Regional People's Representatives Assembly (DPRD) through the respective heads of SKPD which will then be approved by the Governor and DPRD. The governor made a circular (SE) regarding the guidelines for the preparation of the Budget Work Plan (RKA) and the Regional Work Unit carries out inputting the Budget Work Plan (RKA).

The next phase was after all SKPD heads have finished inputting the activity budget, they will get the total amount of the DKI Regional Budget in the form of the Regional Regulation Draft (RAPERDA) APBD which will then be submitted to DPRD for approval. Approval by the DPRD for all SKPD activities into APBD must be evaluated and obtain approval from the Ministry of Home Affairs. In this phase, the Ministry of Home Affairs (Kemendagri) will look at all activities proposed by the DKI Jakarta Provincial Government, if there were activities that were deemed unsuitable, they will be returned back.

Evaluation of the Draft Regional Revenue and Expenditure Budget (RAPBD) that was proposed to the Ministry of Home Affairs was then revised by the Provincial Government of DKI Jakarta. The evaluation will be discussed jointly by the Governor of DKI Jakarta Province, the Provincial DPRD of DKI Jakarta and the related Regional Work Units (SKPD). The discussion will be adjusted to the proposal from the Ministry of Home Affairs. The final phase in the planning phase for the formation of the DKI Jakarta Provincial APBD was the ratification of the Regional Budget stipulation by the Governor of the DKI Jakarta Province and the Regional People's Representative Assembly (DPRD) which is then ratified through the stipulation of the DKI Jakarta Provincial Regulation regarding the DKI Jakarta Provincial Regional Budget (APBD).

DKI Jakarta Provincial Governor Regulation Number 145 of 2013 concerning Preparation of Regional Revenue and Expenditure Budget Draft / Revised Regional Revenue and Expenditure Budget through Electronic Budgeting was the basis for all SKPD / UKPD within the DKI Jakarta Provincial Government to input the budget into the system. Input in the ebudgeting system / application was carried out during the budget planning phase which was inputted by each SKPD / UKPD.

The case that occurred in the DKI Jakarta Provincial Government which occurred at the end of 2019 last year for the 2020 Fiscal Year activities was seen when all SKPD / UKPD had finished inputting the budget and discussions were being held between the Governor of DKI Jakarta Province and the DPRD of the DKI Jakarta Province. Apart from the 4 (four) SKPD / UKPD above, fantastic budget findings were also found by the Governor of DKI Jakarta Province as follows: 
Table 2

Findings of the Budget for the Activities of the Year 2020 budget

\begin{tabular}{clr}
\hline No. & \multicolumn{1}{c}{ Activities } & Total Budget \\
\hline 1. & Bicycle lane construction & 73.7 billion \\
\hline 2. & Printer ink & 407.1 billion \\
\hline 3. & Purchasing Paper & 203.3 billion \\
\hline 4. & Procurement of aibon glue & 82.8 billion \\
\hline 5. & Procurement of ballpoint pens & 124 billion \\
\hline 6. & Procurement of 7,313 computers & 121 billion \\
\hline 7. & Server and storage procurement, & 66 billion \\
\hline
\end{tabular}

Source: Bappeda DKI Jakarta Province

Based on the results of interviews conducted by researchers to the Head of the Regional Planning and Development Agency (Bappeda) and the Head of the Regional Financial Management Agency (BPKD) of DKI Jakarta Province, it was confirmed that there were several activities as mentioned above that had fantastic budgets, the Head of Bappeda and the Head BPKD DKI Jakarta Province also acknowledged that apart from the data above, there were many factors that influence it.

Based on the data above, the problems faced in the use of e-budgeting were errors during budget planning and planning for regional property needs. In addition, when inputting through the ebudgeting application system, the time given was very little, so it was done very hastily which resulted in errors in inputting. Prices and components of goods in the e-budgeting system were not updated with the conditions during the current year which also contributed to constraints in the implementation of ebudgeting. Likewise, there was no other components or items that were not in accordance with SKPD planning, so that SKPD / UKPD had an assumption that the amount of budget proposed was at least similar to the e-budegting system / application. And what was no less important was the existence of political intervention, or activities that were inserted by SKPD / UKPD to support certain political activities.

\section{The suitability of E-budgeting Implementation with Brinkerhoff and Crosby's Theory of Policy Implementation}

Policy implementation theory next was to use the theory put forward by Brinkerho and Crosby (2012) to formulate 6 (six) characteristics of a framework for policy implementation so that these policies can be carried out on an ongoing basis.

Creating legitimacy The first characteristic of policy implementation was that public policies could be accepted as important, as well as desirable, and the policies are worthy of being achieved. Legitimacy means receiving support from the right people in this country / region to drive the reform process going forward. The most important result in the characteristics of policy was the emergence of policies that can be decided by the leader. The main purpose of ebudgeting implemented by the DKI Jakarta Provincial Government was to establish transparency and accountability so that these stakeholders provide support for the creation of e-budgeting for budget management, with the discovery of several cases, the use of e-budgeting systems and applications must be evaluated and improved.

Building constituencies, the second characteristic was to build constituencies, or to get active support for a proposed policy from groups that see rumors or related issues as desired. It supported needs to translate communication 
commitments to take actions that will help to achieve policy goals. In addition to building coalitions of supporters, building constituencies seeks to reduce or reflect the opposition of groups that see proposed reforms as dangerous or threatening. This task should be pursued frequently during implementation to ensure continued support and to resist displacement of DKI Jakarta Provincial Government. The use of e-budgeting applications must get support from all stakeholders so that the purpose of using this application can be achieved;

\section{Accumulating}

resources, accumulation of resources means ensuring that current and future budgets and human resource allocations were adequate to support implementation requirements. Completing this task could involve, for example: lobbying constituencies for donating resources, negotiating with ministries for funding of budget items, designing new resource allocation systems, and / or establishing public-private partnerships. The application of the ebudgeting application must mobilize all available resources so that it can maximize the optimal role of the e-budgeting application for the budgeting process.

\section{Modifying}

organizational

structures, Modifying the organizational structure was the fourth policy implementation task. It required adjusting the objectives, procedures, systems and structures of the institutions responsible for policy implementation. Sometimes this task can also include the creation of a new organization to coordinate various entities with roles in implementation. The current organizational adjustment in the DKI Jakarta Provincial Government for inputting the e-budgeting application must form a separate organization so that it can focus more on the direction and purpose of the formation of this application.

Mobilizing resources and actions, Mobilizing resources and shaping action on top of favorable constituencies pooled for policies (Building constituencies) and mobilizing all their commitments and resources (Accumulating resources) to engage in concrete efforts to make change into something realized. The focus was on identifying, activating and pursuing action. It brought together constituencies and mobilized and mobilized resources, and within the organizational structure that was formed, then developed and implemented the steps necessary to translate the intentions into concrete steps. The DKI Jakarta Provincial Government must be able to mobilize all resources, be it Civil Servants (PNS) or cooperate with other parties (private) to achieve the objectives of this system.

Impact monitoring, Monitoring impact, or setting up a system for monitoring the progress of implementation, was the final policy implementation task. Monitoring systems not only alert decision makers to implementation barriers, but also inform them of the intended and unwanted impacts of implementation efforts. Impact monitoring that must be carried out by the DKI Jakarta Provincial Government was the formation of a team to monitor the ebudgeting system / application so as to know the impact of the implementation of the budget input policy through the system / application.

Based on the findings in this study, it can be understood that the implementation of e-budgeting in DKI Jakarta had not fulfilled the Brinkerhoff and Crosby Policy Implementation Theory. From the Creating legitimacy side, it can be seen that the ebudgeting policy has not been optimally implemented as an important policy. It can be seen from various errors and weaknesses that should be corrected if considered important. Several studies have shown that the use of e-budgeting can make fund management more effective and efficient (Lidia, 2014; Nugraha \& Wibowo, 2020). In fact, the implementation of transparent e-budgeting has proven to be able to reduce the level of corruption 
(Cimpoeru \& Cimpoeru, 2015). Thus, it was only natural that the implementation of e-budgeting was carried out more optimally.

From the point of view of building constituencies, according to the data obtained, technical problems regarding time, price, the mismatch of goods with the planning indicate that the synchronization of the users of this application has not been optimal. In other words, coordination, cooperation and support for this system still needed to be improved. Bearing in mind, in implementing policies, support from all parties was very much needed (Twizeyimana \& Andersson, 2019). Likewise with coordination, especially organizational coordination within the government, it was very necessary to be maintained and improved in order to be able to implement policies properly. (Adam et al., 2019; Arruada \& Buainain, 2013). Improvements in coordination must continue to be made, even though the process did not always run smoothly(Peters, 2018).

Based on the concept of Accumulating resources, which focused on current and future budget allocations and adequate allocation of human resources, it can be said that the implementation of ebudgeting had not been able to fully fulfill this concept. It is due to the implementation of e-budgeting was proven to have resulted in the emergence of inappropriate budgets due to political interests and technical problems that indicate constraints on human resources. In simple terms, the concept of Accumulating Resources is applied to ensure sustainable governance management. Ensuring this sustainability requires strong leadership, stakeholder involvement, participatory approaches and extensive consultations (Dawkins et al., 2019). The success of human resource management was influenced by the leadership's ability to communicate effectively and make subordinates as actors(Kairouz et al., 2016).

Viewed from the point of view of implementing Modifying organizational structures, namely adjusting objectives, procedures, systems, and institutional structures that were responsible for policy implementation, the DKI government did not yet have a special organization that was responsible for the implementation of e-budgeting. An organizational structure that clearly showed who was responsible for certain jobs was very important because with the availability of a clear organizational structure, the implementation of the implementation will be better.(Hall \& O'Toole, 2000; Lindquist, 2006). For this reason, this concept needs to be considered in the implementation of e-budgeting in the DKI Jakarta Government.

Based on the concept of Mobilizing resources and actions, namely identifying, activating, and pursuing action, the DKI Jakarta government, which had identified the problems it was facing, needed to take the necessary corrective actions immediately. Because the sooner a problem was resolved, the faster the process of improving the quality of the implementation of the policy can be achieved(Smith \& Hasan, 2020; Turnbull, 2006). By increasing the quality of implementation, the objectives to be achieved from the implementation of the policy will be easier to achieve.

Furthermore, from the impact monitoring concept, which was to provide a system to monitor the progress of implementation, it can be seen that the DKI Jakarta government had carried out monitoring in the implementation of ebudgeting. It was reflected in the identification of problems that have been carried out. Monitoring was also a very important process to ensure that policy implementation goes based on plan (Waylen et al., 2019). The implementation of policy monitoring often faced obstacles 
because of the many factors that influence the implementation of a policy(Phulkerd et al., 2017). However, given the importance of the monitoring factor, monitoring must continue to be carried out and followed up regardless of all the problems.

Although from the results of this study it was found that in general the implementation of e-budgeting in DKI Jakarta had not been carried out optimally, it should be understood that problems in using technology can be caused by weaknesses in the system itself or weaknesses of users (human factors). (Masouleh et al., 2014; Sari et al., 2019; Sarrayrih \& Sriram, 2015). This study has not seen whether the problems that occurred were due to system weaknesses or because of weaknesses in user capabilities. For this reason, it is necessary to carry out further studies to identify in more detail the sources of problems in the implementation of e-bugeting. Therefore with the results of the study, the handling for improvement can be carried out better.

\section{CONCLUSION}

Input flowbudgets through the ebudgeting application system must go through various stages. In general, these stages started from the collection of aspirations from the lowest levels of government, namely the RT / RW to the regent / mayor. After the aspirations had been collected, the governor and provincial DPRD will discuss them again before submitting them to the Minister of Home Affairs. The proposals submitted to the Minister of Home Affairs were then evaluated if there were things that were not appropriate, the Minister of Home Affairs will provide recommendations for revision by the Governor together with the Provincial DPRD. After it had been declared appropriate, the Governor determined it. Issues that become obstacles in the implementation of e-budgeting in the DKI Jakarta Government were errors during budget planning and planning for regional property needs, short data entry times, prices and components of goods in the ebudgeting system were not up to date, there were no components or other items that were not in accordance with SKPD planning, and there were political interventions to support certain political activities. Based on Brinkerhoff and Crosby's policy implementation theory, it can be concluded that the e-budgeting implementation in DKI Jakarta still needed to be refined. It can be seen from the various problems that occurred in the implementation of e-budgeting that have not fully met the criteria with this theory.

\section{BIBLIOGRAPHY}

Adam, C., Hurka, S., Knill, C., Peters, B. G., \& Steinebach, Y. (2019). Introducing Vertical Policy Coordination to Comparative Policy Analysis: The Missing Link between Policy Production and Implementation. Journal of Comparative Policy Analysis: Research and Practice, 21(5), 499-517. https://doi.org/10.1080/13876988.2019.15 99161

Andriyanto, D., Baridwan, Z., \& Subekti, I. (2019). Anteseden Perilaku Penggunaan E-budgeting: Kasus Sistem Informasi Keuangan Desa di Banyuwangi, Indonesia. Jurnal Dinamika Akuntansi Dan Bisnis, 6(2), 151-170. https://doi.org/10.24815/jdab.v6i2.13938

Arruada, J. P. de, \& Buainain, A. M. (2013). Organizational Coordination in Public Policy Implementation: Practical Dimensions and Conceptual Elements. Central European Journal of Public Policy, 7(December), 136159.

Cimpoeru, M. V., \& Cimpoeru, V. (2015). Budgetary Transparency: An Improving Factor for Corruption Control and Economic Performance. Procedia Economics and Finance, 27, 579-586. https://doi.org/10.1016/s22125671(15)01036-9

Dawkins, E., André, K., Axelsson, K., Benoist, L., Swartling, Å. G., \& Persson, A. (2019). Advancing sustainable consumption at the local government level: A literature review. Journal of Cleaner Production, 231, 14501462. https://doi.org/10.1016/j.jclepro.2019.05.1 76

Eduardo Araral, Scott Fritzen, Michael Howlett, M. Ramesh, X. W. (Ed.). (2012). Teori 
Implementasi Kebijakan Brinkerhoff dan Crosby. In Routledge Handbook of Public Policy. Routledge.

Hall, T. E., \& O’Toole, L. J. (2000). Structures for Policy Implementation. Administration \& Society, 31(6), 667-686. https://doi.org/10.1177/009539900220192 81

Kairouz, A., Hokayem, J. El, \& Hage, U. El. (2016). Sustainability of Public Management in the Developing Countries: The Case of Lebanon. Procedia-Social and Behavioral Sciences, 221, 378-387. https://doi.org/10.1016/j.sbspro.2016.05.1 33

Khoirunnisak, R., Arishanti, D., \& Vebrianti, D. D. (2017). Penerapan E-budgeting Pemerintah Kota. Prosiding Seminar Nasional Dan Call For Paper Ekonomi Dan Bisnis, 27-28. https://jurnal.unej.ac.id/index.php/prosidin g/article/view/6715

Lidia, T. G. (2014). Difficulties of the Budgeting Process and Factors Leading to the Decision to Implement this Management Tool. Procedia Economics and Finance, 15, 466473. https://doi.org/10.1016/s22125671(14)00484-5

Lindquist, E. (2006). Organizing for policy implementation: The emergence and role of implementation units in policy design and oversight. Journal of Comparative Policy Analysis: Research and Practice, 8(4), 311324.

https://doi.org/10.1080/138769806009708 64

Masouleh, Z. D., Allahyari, M. S., \& Atani, R. E. (2014). Operational indicators for measuring organizational e-readiness based on fuzzy logic: A challenge in the Agricultural Organization of Guilan Province, Iran. Information Processing in Agriculture, 1(2), 115-123.

https://doi.org/10.1016/j.inpa.2014.11.002

Miles, M. B., \& Huberman, M. a. (1994). Qualitative data analysis: An expanded sourcebook. In Evaluation and Program Planning (Vol. 19, Issue 1 , pp. 106-107). https://doi.org/10.1016/0149$7189(96) 88232-2$

Moleong, J. (2010). Metodologi Kualitatif. Remaja Rosdakarya.

Naihasy, S. (2006). Kebijakan Publik: Menggapai Masyarakat Madani. Mida Pustaka.

Nasution, A. P., \& Atika. (2019). Implementasi Ebudgeting sebagai Upaya Peningkatan Transparansi dan Akuntabilitas Pemerintah Daerah Kota Binjai. Jurnal Akuntansi Bisnis Dan Publik, 9(2), 1-13. http://jurnal.pancabudi.ac.id/index.php/aku ntansibisnisdanpublik/article/view/454

Nugraha, A. Y., \& Wibowo, U. B. (2020). Analysis of Benefits and Obstacles from E-budgeting Implementation in Educational Organizations. Proceedings of the International Conference on Educational Research and Innovation (ICERI) 2019. https://doi.org/10.2991/assehr.k.200204.0 01

Peters, B. G. (2018). The challenge of policy coordination. Policy Design and Practice, 1(1), 1-11.

https://doi.org/10.1080/25741292.2018.14 37946

Phulkerd, S., Sacks, G., Vandevijvere, S., Worsley, A., \& Lawrence, M. (2017). Barriers and potential facilitators to the implementation of government policies on front-of-pack food labeling and restriction of unhealthy food advertising in Thailand. Food Policy, 71, 101110.

https://doi.org/10.1016/j.foodpol.2017.07.0 14

Sakapurnama, E., \& Safitri, N. (2012). Good governance aspect in implementation of the transparency of public information law. Bisnis \& Birokrasi, Jurnal Ilmu Administrasi Dan Organisasi, 19(1), 69-78.

Sari, L. G. E., Yuesti, A., Sudja, I. N., \& Kepramareni, P. (2019). Analysis of Budget Planning, Competence of Human Resources and Implementation of the Viii Lldikti Region Budget with Organizational Commitment as A Moderation. International Journal of Contemporary Research and Review, 10(02), 21273-21288. https://doi.org/10.15520/ijcrr.v10i02.655

Sarrayrih, M. A., \& Sriram, B. (2015). Major challenges in developing a successful egovernment: A review on the Sultanate of Oman. Journal of King Saud University Computer and Information Sciences, 27(2), 230-235.

https://doi.org/10.1016/j.jksuci.2014.04.00 4

Silaen, S. (2013). Metodologi Penelitian Sosial untuk Penulisan Skripsi dan Tesis. In Media.

Smith, J. D., \& Hasan, M. (2020). Quantitative approaches for the evaluation of implementation research studies. Psychiatry Research, 283, 112521. https://doi.org/10.1016/j.psychres.2019.11 2521

Turnbull, N. (2006). How Should We Theorise Public Policy? Problem Solving and Problematicity. Policy and Society, 25(2), 3-22. https://doi.org/10.1016/s14494035(06)70072-8 
Twizeyimana, J. D., \& Andersson, A. (2019). The public value of E-Government: A literature review. Government Information Quarterly, 36(2), 167-178. https://doi.org/10.1016/j.giq.2019.01.001

Waylen, K. A., Blackstock, K. L., van Hulst, F. J., Damian, C., Horváth, F., Johnson, R. K., Kanka, R., Külvik, M., Macleod, C. J. A., Meissner, K., Oprina-Pavelescu, M. M., Pino, J., Primmer, E., Rișnoveanu, G., Šatalová, B., Silander, J., Špulerová, J., Suškevičs, M., \& Uytvanck, J. Van. (2019). Policy-driven monitoring and evaluation: Does it support adaptive management of socio-ecological systems? Science of The Total Environment, 662, 373384.

https://doi.org/10.1016/j.scitotenv.2018.12 .462

Zarnelly. (2017). Sistem Informasi E-budgeting Menggunakan Pendekatan Berorientasi Objek (Studi Kasus: Uin Suska Riau). Jurnal Ilmiah Rekayasa Dan Manajemen Sistem Informasi, 3(1), 70-77. http://ejournal.uinsuska.ac.id/index.php/RMSI/article/downlo ad/3449/2056. 